\title{
4
}

\section{Australia’s Extraterritorial Border Control Policies}

\author{
Azadeh Dastyari and Asher Hirsch
}

By international standards, the numbers of refugees arriving in Australia irregularly are small. Nevertheless, Australia has instigated extreme policies to deter and deny people seeking its protection. The impacts of these policies are felt by some of the world's most vulnerable individuals: refugees. For such individuals, the overall numbers are irrelevant because the harm caused to them is personal and real. Australia's policies are also undermining the international protection regime by setting a harmful example for other states who wish to deny refugees protection. In this way, Australia's impact on global protection is disproportionate to the size of the cohort of irregular arrivals.

The majority of spontaneous arrivals in Australia (i.e., the arrival of individuals without visas or other legal authority to enter the country) are refugees. A refugee is defined in Article 1(A)(2) of the Convention Relating to the Status of Refugees (Refugee Convention) as a person who, "owing to well-founded fear of being persecuted for reasons of race, religion, nationality, membership of a particular social group or political opinion, is outside the country of his nationality and is unable or, owing to such fear, is unwilling to avail himself of the protection of that country."

A person who meets this definition is considered a refugee with rights under international law from the moment they meet the definition, not from the moment their claim for protection is assessed. As the United Nations High Commissioner for Refugees (UNHCR) handbook makes clear:

[a] person is a refugee within the meaning of the 1951 Convention as soon as he fulfils the criteria contained in the definition. This would necessarily occur prior to the time at which his refugee status is formally determined. Recognition of his refugee status does not therefore make him a refugee but declares him to be one. He does not become a refugee because of recognition, but is recognized because he is a refugee. ${ }^{1}$

1 United Nations High Commissioner for Refugees, Handbook on Procedures and Criteria for Determining Refugee Status under the 1951 Convention and the 1967 Protocol Relating to the Status of Refugees (Geneva, Switzerland: United Nations High Commissioner for Refugees, 
This distinction is significant because it means that a person who meets the definition of a refugee is a refugee even if they are prevented from accessing protection. That is, extraterritorial measures adopted by Australia, or any other country, which prevent the entry of a refugee, do not negate the status of the individual as a rights holder under international law.

In the last two decades, refugee arrivals in Australia have included Hazara and other Afghani refugees escaping the violence of the Taliban; Iraqi refugees fleeing sectarian violence in their war-torn state; and members of the LGBTQI community, political activists, evangelical Christians, and other persecuted minority groups fleeing the Iranian regime. Such individuals make the difficult and dangerous journey to Australia in search of safety because they have little choice.

Almost all such refugees pass through transit states in Southeast Asia, such as Indonesia and Malaysia, to reach Australia. They are unable to seek protection in these transit countries because these states have not ratified the Refugee Convention and therefore do not have any legal obligation to offer refugees protection. The refugees in transit states are often left without legal status in a precarious and at times dangerous situation. The ability of the refugees to come to Australia and find protection, therefore, is paramount for their safety.

Refugees arriving irregularly to Australia, however, have not been viewed favorably by successive Australian governments. Policies that deter and deny refugees access to Australian territory, regardless of their desperation or need, have enjoyed bipartisan support from both Australia's center-left Labor party and the center-right Liberal and National Coalition parties. Governments wishing to exercise a high degree of control over Australian borders have also been assisted by the country's geography. Australia's isolation and lack of land borders has helped it to implement a number of extraterritorial migration control measures, that is, actions outside of Australian territory that allow it to prevent the irregular arrival of refugees by both sea and air. These "non-entrée policies" effectively stop would-be refugees from leaving their own countries, or keep refugees in countries that have not ratified the Refugee Convention and that have less capacity to protect refugees and uphold their rights.

Many of the extraterritorial border control measures adopted by Australia have focused on stopping irregular boat arrivals. Refugees arriving by boat, in particular, have been viewed as a grave risk to Australian society. ${ }^{3}$ Stopping the refugee boats

2011), - 28, www.refworld.org/docid/4f33c8d92.html; J. C. Hathaway and M. Foster, The Law of Refugee Status (2nd ed., Cambridge: Cambridge University Press, 2014), 25.

2 J. C. Hathaway, The Rights of Refugees under International Law (New York: Cambridge University Press, 2005), 291.

3 F. H. McKay, S. L. Thomas, and R. W. Blood, “Any One of These Boat People Could Be a Terrorist for All We Know!' Media Representations and Public Perceptions of 'Boat People' Arrivals in Australia” (2011) 12(5) Journalism 607-626. 
was a key election promise of the Coalition government in its re-election campaign in 2013 . Australia has also introduced less publicized measures to prevent the entry of unauthorized non-citizens by air.

This chapter addresses some of the extraterritorial measures adopted by Australia to prevent the entry of certain people into Australian territory. In the first part, the chapter examines measures aimed at stopping irregular arrivals by air, including carrier sanctions, Airline Liaison Officers, and the use of technology. The second part assesses the measures taken by Australia to stop irregular boat arrivals, including third country detention and processing regimes in Nauru and Papua New Guinea and boat interdictions. The final part questions the legality or otherwise of Australia's actions.

Extraterritorial border control measures have proven highly effective in preventing the irregular arrival of refugees in Australia. They have, however, placed Australia in violation of its international obligations, prevented refugees from seeking protection thereby placing them in harm's way, and have resulted in great suffering for at-risk groups.

\section{STOPPING THE PLANES}

People seeking to claim protection in Australia have two options to enter Australia's territory and seek its protection: arrival by plane or by boat. The waters surrounding Australia are often treacherous and the boat journey to Australia can be deadly. Furthermore, people travelling irregularly by boat seldom have choice in the vessel used to carry them and can end up on unseaworthy boats that cannot cope with rough waters or precarious weather conditions. Although allowing asylum seekers and refugees to board a plane to Australia would be the safer option, Australia has gone to great lengths to ensure that those without a visa are unable to board an Australia-bound flight.

\section{Carrier Sanctions}

One of the most significant means by which Australia prevents the entry of refugees into its territory by air is through fines for airline operators in the form of carrier sanctions. Carrier sanctions are financial penalties imposed upon airlines and ships that transport passengers who do not hold the relevant permission to enter the country. By requiring carriers to check that passengers have authorization to enter a country prior to embarking, carriers effectively become border officials, controlling migration at the point of departure. Although carrier sanctions do not apply only to those who carry refugees, they disproportionally affect refugees seeking protection.

Carrier sanctions rely on an economic argument: The "fear of having their profit margin eroded by such penalties is supposed to encourage carriers to deny passage to 
Australia to those who are inadequately or irregularly documented." "The Australian Migration Act of 1958 (Cth) makes it an offence to transport a non-citizen to Australia without a visa or documentation. ${ }^{5}$ In addition, airlines and ship companies are responsible for removing passengers from Australia if they are refused entry after arrival.

To make it explicitly clear that carrier sanctions apply even to those with genuine protection claims, Section 228B(2) of Australia's Migration Act provides: "a noncitizen includes a reference to a non-citizen seeking protection or asylum (however described), whether or not Australia has, or may have, protection obligations in respect of the non-citizen because the non-citizen is or may be a refugee, or for any other reason." This makes it clear that airlines and other carriers will be fined even if the non-citizen they have brought to Australia is found to be a refugee and owed legal protection in Australia. This is in contrast to the policies of other countries. ${ }^{6}$ For example, in the European Union, sanctions "may in some cases be waived if the passenger is found to be a refugee." 7 However, since carriers do not conduct refugee status determinations prior to boarding, the changes of an airline allowing refugeeclaimant to board a plane - and thereby risk a fine - are slim.

Taylor argues that carrier sanctions have succeeded in reducing the number of refugees arriving by air: "The fact that the number of infringement notices actually served on carriers has been dropping markedly from year to year indicates that sanctions have had their intended effect." ${ }^{8}$ Airlines are unlikely to be sympathetic to the claims of refugees seeking to board, and even if they are, they do not have adequate expertise to assess refugee claims before departure. Even for those who are sympathetic, the financial impact of carrier sanctions would eventually outweigh any humanitarian concern. ${ }^{9}$

Carrier sanctions mean that refugees are stopped outside of Australian territory before they board the plane - and that the process of border control is carried out by a private company. ${ }^{10}$ This privatization of border control adds an additional complication for those seeking protection. There are legal implications when private

4 S. Taylor, "Offshore Barriers to Asylum Seeker Movement: The Exercise of Power without Responsibility?," in J. McAdam (ed.), Forced Migration, Human Rights and Security (Oxford: Hart Publishing, 2008), p. 100.

5 Migration Act 1958, No. 62, 1958, $\iint 229,232$.

6 A. Brouwer and J. Kumain, "Interception and Asylum: When Migration Control and Human Rights Collide" (2003) 21(4) Refuge: Canada's Journal on Refugees 6-24 at 10; Taylor, "Offshore Barriers to Asylum Seeker Movement," p. 101.

7 T. Baird, "Carrier Sanctions in Europe: A Comparison of Trends in 10 Countries" (2017) 19(3) European Journal of Migration and Law 307-334 at 326.

8 Taylor, "Offshore Barriers to Asylum Seeker Movement," p. 100.

9 Ibid., p. 101.

${ }^{10}$ S. Scholten, "The Privatisation of Immigration Control through Carrier Sanctions: The Role of Private Transport Companies in Dutch and British Immigration Control," in J. Niessen and E. Guild (eds.), Immigration and Asylum Law and Policy in Europe (vol. 38, Leiden, Boston: Brill Nijhoff, 2015). 
commercial companies rather than a government official decide if a person has the right to cross the border. This is because states rather than private companies have the legal responsibility to refugees under international law, and it can be more difficult to hold states accountable when they exercise their power through private companies. As Gammeltoft-Hansen notes, "the argument that states incur any obligations under refugee law as a result of carrier controls has been rejected on the premise that these controls are a private matter, distinct from the state's own authorities and thus responsibility."11 This makes asserting legal rights such as nonrefoulement, increasingly difficult, successfully deterring many potential legal challenges.

\section{Airline Liaison Officers}

Although it has privatized border controls through carrier sanctions, Australia has not entirely relinquished its border control at airports to airlines. In order to assist airlines in meeting their carrier obligations, Australia has posted Airline Liaison Officers (ALOs) in more than sixteen airports throughout Asia and the Middle East, as these countries are often seen as transit countries for asylum seekers en route to Australia. By its own account, "Australia has one of the most experienced, respected and effective ALO networks in the world."

The main function of ALOs is to "assist local immigration and airport authorities and airlines personnel to identify document fraud by checking documents and provide advice on authenticity."13 As the Department of Immigration describes, "ALOs work with airlines, airport security groups and host governments, as well as colleagues from other countries, and have a dual role of preventing improperly documented passengers from travelling and facilitating the travel of genuine passengers at key overseas airports." 14 In 2014, ALOs prevented "173 improperly documented passengers from travelling to Australia." ${ }^{15}$ It is not clear how many of these passengers had attempted to make asylum claims. "The Department of Immigration's arrangements with host country governments do not specify processes for dealing with asylum claims made by intercepted persons." ${ }^{16}$

11 T. Gammeltoft-Hansen, Access to Asylum: International Refugee Law and the Globalisation of Migration Control, Cambridge Studies in International and Comparative Law (Cambridge: Cambridge University Press, 2011), p. 17.

12 S. Morrison, "New Measures at Our Borders to Protect against Terrorist Threat," September 10, 2014, https://parlinfo.aph.gov.au/parlInfo/search/display/display.w3p;query=Id:\%22media/press $\mathrm{rel} / 3387218 \% 22$.

13 Taylor, "Offshore Barriers to Asylum Seeker Movement," p. 95.

14 Department of Immigration and Border Protection, 2014-2015 Annual Report (2015), 92, www .border.gov.au/ReportsandPublications/Documents/annual-reports/DIBP-Annual-Report-201415-optimised.pdf.

15 Ibid.

16 Taylor, "Offshore Barriers to Asylum Seeker Movement," p. 97. 
The aim of the ALO network is to "extend [the Australian] border all the way to embarkation points. ${ }^{\prime 7}$ However, the direct impact of ALOs is difficult to quantify, as there is no record keeping of any refugee claims made at the departure point. ${ }^{18}$ This has been noted at a roundtable with the UNHCR and the Council of Europe: "It is impossible to be precise about the number of refugees who are denied escape due to stringent checks by transport companies. The number is considered to be on the rise, however, not least since transport companies have been assisted by Governmental liaison officers in verifying travel documents." ${ }^{19}$

\section{Use of Technology}

Finally, to ensure compliance with its carrier sanctions and to further monitor and control its external borders, Australia maintains a range of surveillance technologies. The Department of Immigration's Annual Report 2014-2015 highlights a number of "Border Systems" it employs to monitor and control the movement of passengers en route to Australia. These include systems to identify "people who are of concern for a number of reasons, including health, character and national security"; to record "lost, stolen or cancelled and bogus foreign travel documents"; and to share "realtime travel document validation service between participating RMAS [regional movement alert system] economies - currently Australia, New Zealand, the USA and the Philippines." ${ }^{20}$ As the Department notes, these systems ensure that "people tendering invalid travel documents [are] prevented from boarding a flight from any boarding point." ${ }^{\prime 21}$

Since 2005, Australia has required all airlines to process passengers through the Advance Passenger Processing ("APP") system. ${ }^{22}$ The Department of Immigration outlines how this process works:

Airlines bringing travellers to Australia are required to confirm that each traveller they uplift has an authority to travel to Australia, usually in the form of a visa. Airlines confirm this authority using the advance passenger processing (APP) system, which also reports details of all passengers and crew to the Department before arrival. This gives the Department and other agencies advance notice in real time of a person arriving by air and helps to facilitate immigration clearance of genuine travellers on arrival. ${ }^{23}$

${ }_{17}$ Morrison, "New Measures at Our Borders to Protect against Terrorist Threat."

18 Taylor, "Offshore Barriers to Asylum Seeker Movement," p. 98; Brouwer and Kumain, "Interception and Asylum," p. 10.

19 Brouwer and Kumain, "Interception and Asylum" at 11.

${ }^{20}$ Department of Immigration and Border Protection, 2014-2015 Annual Report, p. 91.

${ }^{21}$ Ibid.

22 Taylor, "Offshore Barriers to Asylum Seeker Movement," p. 99.

23 Department of Immigration and Border Protection, 2014-2015 Annual Report, p. 92. 
Since 2006, Australia has also developed an extensive database of biometric data for all non-citizens. ${ }^{24}$ In 2004, the Australian Parliament passed the Migration Legislation Amendment (Identification and Authentication) Act 2004 (Cth). This Act allows for the collection of personal identifiers from non-citizens, including fingerprints and handprints, photographs or other images of the face and shoulders, weight and height measurements, audio or video recordings, signatures and iris scans, and other items. ${ }^{25}$ This data is shared with other partner nations and crossreferenced to identify any undesirable people. As the Department explains:

Under the Five Country Conference (FCC) biometric data matching programme, the Department is developing capability to automate the exchange of non-FCC citizens' biometric data with other FCC partners. Automation of biometric data exchange has begun between Australia and the USA, and between Australia and the UK. Full automation of biometric data exchange, and the subsequent legal requirements to carry out this sharing, will be progressively rolled out to all FCC partners over the coming years. ${ }^{26}$

This data matching has led to the denial of visas to potential refugees. For example, the Australian government has published the following case study:

An individual applied for a visitor visa at an overseas post on 24 February 2015. The individual's biometrics were captured and referred for FCC checking. One partner country returned an FCC match in March 2015 and advised that on 19 December 2008 the individual had been apprehended by immigration and customs officials and charged with being an undocumented arrival. The individual left the partner country on 27 March 2009 .... A second FCC country also returned a fingerprint match and revealed that the individual had applied for refugee protection there. In March 2005 the individual was reported inadmissible for being a member of an organised crime group that specialised in the theft of money and jewellery. It was also reported that the individual had been convicted on 10 August 2005 of an offence punishable by a maximum term of imprisonment of at least 10 years, or for which a term of imprisonment of more than six months was imposed .... The individual's application for an Australian visitor visa was refused at post on 8 April $2015 .{ }^{27}$

In this example, the potential refugee was not given a chance to present his case, had no rights to appeal, and no access to justice. It should be remembered that under

\footnotetext{
24 Ibid., p. 51.

25 Parliament of the Commonwealth of Australia, House of Representatives, Explanatory Memorandum, Migration Legislation Amendment (Identification and Authentication) Bill 2004 (2003), - 7, http://parlinfo.aph.gov.au/parlInfo/download/legislation/ems/r175o_ems_ ad5o8d33-2128-4588-9020-c8660227eceo/upload_pdf/57737.pdf;fileType=application\%2Fpdf.

26 Department of Immigration and Border Protection, 2014-2015 Annual Report, p. 50.

27 Ibid., p. 51.
} 
international law, being convicted of theft does not automatically make a person ineligible for refugee protection. ${ }^{28}$ The example shows how these technologies of surveillance can work to keep out potential refugee claimants.

Those who are unable to board a plane to Australia are forced to seek refugee protection by boat. Indeed, it could be argued that the creation of visa controls and airline liaison officers has forced those seeking protection to use more dangerous pathways to protection. Those who are unable to obtain a visa have very few options at their disposal to protect themselves and their families. However, in response to the irregular arrival of refugees by boat, Australia has further hardened its border, implementing a range of discriminatory policies directed at boat arrivals.

\section{STOPPING THE BOATS}

\section{Extraterritorial Processing and Detention of Asylum Seekers and Refugees Arriving by Boat}

Much of Australia's current extraterritorial practices with regard to irregular boat arrivals were a response to the August 2001 arrival of the Norwegian-registered MV Tampa near Australian territory. MV Tampa, which was carrying 433 asylum seekers rescued at sea, attempted to enter Australian territorial waters and to disembark the rescued people on Australian territory of Christmas Island. The Australian government, then led by Prime Minister John Howard from the center-right Liberal party, in coalition with the National Party (which largely represents the more conservative rural communities in Australia), responded by deploying military (Special Air Services) personnel to take control of the vessel and forcibly transfer the passengers to Nauru for processing.

These events marked the commencement of a policy broadly known as the "Pacific Solution," under which any non-citizens, including refugees, interdicted at sea or arriving in certain parts of Australia without a valid visa to enter Australian territory, became vulnerable to transfer to Australia's economically struggling former protectorates of Nauru and Papua New Guinea for processing and detention.

Due to a drop in the number of boat arrivals, the number of asylum seekers transferred to Manus Island in Papua New Guinea decreased over time. By May 2005, there were no detainees in the Papua New Guinea facility. However, detention in Nauru continued until December 2007, when it was ended by Australia's newly elected center-left Labor government. The closure of the facilities in Nauru and Papua New Guinea was, however, short lived.

The Labor government announced the resumption of the transfer of asylum seekers to Nauru and Papua New Guinea in August 2012, and in July 2013 it was announced that no refugees processed in Nauru or Manus Island would ever be

${ }^{28}$ Hathaway and Foster, The Law of Refugee Status, p. 546. 
resettled in Australia. Instead, asylum seekers would be sent to Nauru or Manus Island, and then, following the confirmation of refugee status, would either be expected to resettle in Nauru, Papua New Guinea, or a third country.

Australia has, however, found it difficult to resettle refugees from Nauru and Papua New Guinea. Cambodia agreed to resettle refugees from Nauru in exchange for $\$ 55$ million from the Australian Government. Only seven refugees agreed to participate in the arrangement. ${ }^{29} \mathrm{~A}$ highly publicized deal with the United States has also resulted in the resettlement of refugees from Nauru and Papua New Guinea. ${ }^{30}$ As of August 22, 2019, a total of 619 refugees had been resettled in the United States. ${ }^{31}$ An offer by New Zealand to resettle refugees from Australia's extraterritorial detention centers has been rejected by the Australian government. ${ }^{32}$ The Australian government fears that the refugees resettled in New Zealand may be able to enter Australia later as a result of a special category visa for New Zealand citizens, which allows them to live and work in Australia indefinitely. ${ }^{33}$ Between August 13, 2012, and September 1, 2019, 4,177 people were transferred to Nauru and Papua New Guinea, including children. In September 2019, 562 of the people transferred by Australia to Nauru and Papua New Guinea remained on the islands. No children remain on Nauru and Manus Island as of January 2020.

The cost of operating detention facilities in Nauru and Manus Island are borne entirely by Australia. Australia has contracted service providers and maintains a visible and active presence at the centers at all times. As the UNHCR notes, "it is clear that Australia has retained a high degree of control and direction in almost all aspects of the bilateral transfer arrangements." 34 The High Court of Australia has found that Australia secures, funds, and participates in the detention on Nauru, with Justice Bell further arguing that "[t]he Commonwealth funded the RPC and exercised effective control over the detention of the transferees through the contractual obligations it imposed on Transfield .... [D]etention in Nauru was, as a

29 M. Walden, "Cambodia: Syrian Refugee Secretly Arrives from Australian Detention on Nauru," Asian Correspondent, May 26, 2017, https://asiancorrespondent.com/2017/05/cambo dia-syrian-refugee-secretly-arrives-australian-detention-nauru/.

30 C. Packham, "Exclusive: Australia to Accept First Central American Refugees under U.S. Deal - Sources," Reuters, July 25, 2017, www.reuters.com/article/us-usa-trump-australia-refu gees-idUSKBNiAAoNO.

${ }^{31}$ H. Davidson, "Manus and Nauru Refugees in Australia on Medical Grounds Can Apply for US Move," The Guardian, September 6, 2019, www.theguardian.com/australia-news/2019/sep/o6/ manus-and-nauru-refugees-in-australia-on-medical-grounds-can-apply-for-us-move.

${ }^{2}$ K. Murphy, "Jacinda Ardern Tells Scott Morrison New Zealand Remains Open to Resettling Nauru Refugees," The Guardian, December 5, 2019, www.theguardian.com/australia-news/ 2019/dec/o5/jacinda-ardern-tells-scott-morrison-new-zealand-remains-open-to-resettling-naururefugees.

33 Ibid.

34 United Nations High Commissioner for Refugees, UNHCR Monitoring Visit to the Republic of Nauru 7-9 October 2013 (November 26, 2013), p. 23 \128, www.unhcr.org/publications/legal/ 58117b931/unhcr-monitoring-visit-to-the-republic-of-nauru-7-to-9-october-2013.html. 
matter of substance, caused and effectively controlled by the Commonwealth parties." 35

The detention of asylum seekers in Papua New Guinea and Nauru has received a high degree of criticism from international organizations, including Human Rights Watch, the United Nations High Commissioner for Refugees, and Amnesty International. There have been several deaths of asylum seekers in the detention facility in Papua New Guinea, including the murder of a young Iranian man by guards and the deaths of two men, which a number of leading health professionals believe could have been prevented with better medical care. ${ }^{36}$ The detention facility in Nauru has not been free from tragedy, either. Omid Masoumali, a young Iranian national seeking Australia's protection died after a 22-hour delay to fly him to Australia for burn treatment. Masoumali self-immolated following a UN visit to Nauru in protest against the conditions and continuing detention on the island. ${ }^{37}$ Centers in both Papua New Guinea and Nauru have also been plagued by allegations of rape and other sexual assaults, including of children. Independent bodies have also observed overcrowding and poor conditions of detention, ${ }^{38}$ a lack of fairness and transparency in refugee status determinations, ${ }^{39}$ and repeated concerns regarding detainees' lack of safety. ${ }^{40}$

The UNHCR released a very strong condemnation of conditions for detainees on Australia's extraterritorial detention facilities, stating:

35 Plaintiff M68/2015 v. Minister for Immigration and Border Protection, 257 CLR 42 (HCA 2016).

${ }^{6}$ B. Doherty, "Border Force Doctor Knew of Manus Asylum Seeker's Deteriorating Health before Death,” The Guardian, August 9, 2017, www.theguardian.com/australia-news/2017/aug/ og/border-force-doctor-knew-of-manus-asylum-seekers-deteriorating-health-before-death; G. Thompson et al., “Asylum Seeker's Death Blamed on 'Pathetic' Manus Island Blunder," ABC News, April 25, 2016, www.abc.net.au/news/2016-o4-25/manus-island-blunder-blamedfor-asylum-seeker-death/7355858.

37 Amnesty International, Australia: Island of Despair: Australia's "Processing" of Refugees on Nauru (October 2016), p. 19.

$3^{8}$ Amnesty International, This Is Breaking People: Human Rights Violations at Australia's Asylum Seeker Processing Centre on Manus Island, Papua New Guinea (December 2013), www .refworld.org/pdfid/52aac41cb.pdf; Amnesty International, This Is Still Breaking People: Update on Human Rights Violations at Australia's Asylum Seeker Processing Centre on Manus Island, Papua New Guinea (May 2014), https://static.amnesty.org.au/wp-content/ uploads/2016/og/This_is_still_breaking_people_update_from_Manus_Island.pdf; Senate Legal and Constitutional Affairs Legislation Committee et al., Incident at the Manus Island Detention Centre from 16 February to 18 February 2014 (Parliament of Australia, 2014), www .aph.gov.au/Parliamentary_Business/Committees/Senate/Legal_and_Constitutional_Affairs/ Manus_Island/Report.

39 Human Rights Watch, World Report 2015: Papua New Guinea (New York: Human Rights Watch, 2015), www.hrw.org/world-report/2015/country-chapters/papua-new-guinea.

$4^{\circ}$ Amnesty International, This Is Breaking People; Amnesty International, This Is Still Breaking People; Human Rights Watch, World Report 2015; Senate Legal and Constitutional Affairs Legislation Committee et al., Incident at the Manus Island Detention Centre from 16 February to 18 February 2014. 
There is no doubt that the current policy of offshore processing and prolonged detention is immensely harmful .... Despite efforts by the Governments of Papua New Guinea and Nauru, arrangements in both countries have proved completely untenable. $^{41}$

In 2016, the Papua New Guinea Supreme Court held in Namah v. Pato that detention of refugees and asylum seekers was unconstitutional under the right to liberty set out in the Papua New Guinean Constitution. The Court ordered both the Australian and Papua New Guinea governments to "take all steps necessary to cease and prevent the continued unconstitutional and illegal detention of the asylum seekers or transferees ... on Manus Island." ${ }^{2}$

The detention center on Manus Island has now closed but there is little certainty regarding the fate of the refugees there as their resettlement appears untenable. A number of refugees have required medical attention following assaults from members of the local population after being released into the community, and there are deep concerns regarding the safety of the men transferred to Manus Island by Australia. ${ }^{43}$ The men are vulnerable because of the animosity felt by some members of the local community toward them. As Grewcock explains, "the tensions between sections of the local Manus Island community and the detainees are rooted in the socio-economic impacts of locating the centre in one of the poorer regions of PNG." 44 Human rights groups also report that refugees have been attacked on a daily basis in Nauru after being released into the Nauruan community. ${ }^{45}$

Australia has paid a high cost for its extraterritorial status determination and detention regime for asylum seekers and refugees. In financial terms, the operation of detention facilities in Nauru and Manus Island cost Australia nearly \$5 billion between 2012 and $2017 \cdot{ }^{4^{6}}$ The extraterritorial regime has also been highly damaging to Australia's international reputation with a negative impact on its diplomacy and

${ }^{41}$ United Nations High Commissioner for Refugees, "UNHCR Calls for Immediate Movement of Refugees and Asylum-Seekers to Humane Conditions,” May 2, 2016, www.unhcr.org/en-au/ 572862016.pdf\#zoom=95.

42 Namah v. Pato, Papua New Guinea Supreme Court (2016), 8 ฯ 17.

43 A. Dastyari and M. O'Sullivan, "Not for Export: The Failure of Australia's Extraterritorial Processing Regime in Papua New Guinea and the Decision of the PNG Supreme Court in Namah (2016)" (2016) 42 Monash University Law Review 308-338 at 308.

44 M. Grewcock, "Our Lives Is in Danger': Manus Island and the End of Asylum” (2017) 59(2) Race E Class at 78, https://doi.org/10.1177/0306396817717860.

45 See "Claims Probed of Brutal Conditions for Refugees on Island of Nauru," NPR, August 11, 2016, www.npr.org/2016/08/11/489584342/claims-probed-of-brutal-conditions-for-refugees-onisland-of-nauru. See also M. G. Bochenek, "Australia: Appalling Abuse, Neglect of Refugees on Nauru," Human Rights Watch, August 2, 2016, www.hrw.org/news/2016/08/oz/australiaappalling-abuse-neglect-refugees-nauru.

$4^{6}$ R. Strating, "Enabling Authoritarianism in the Indo-Pacific: Australian Exemptionalism" (2020) 74(3) Australian Journal of International Affairs 301-321, https://doi.org/10.1080/103577 18.2020 .1744516 . 
soft power. ${ }^{47}$ The greatest cost of Australia's determination to process and detain asylum seekers and refugees offshore has, however, been borne by the asylum seekers and refugees themselves.

\section{Interdiction at Sea}

In addition to an extraterritorial processing and detention regime for people who arrive irregularly by boat, Australia has also attempted to prevent refugees from arriving by boat through an interdiction regime. "Interdiction" in this context means actions taken at sea to prevent vessels from reaching their intended destination, in this case Australia. ${ }^{4}$

Australia initially introduced an interdiction program named "Operation Relex" in 2001. While this regime was in effect, twelve vessels were detected attempting to reach Australia. Of these, four were successfully intercepted and returned to Indonesia, three ultimately sank, and the rest were intercepted and passengers were taken to Christmas Island, Nauru, or Papua New Guinea. ${ }^{49}$

Under the Labor Government, from 2007 to 2013, no boats were turned back. However on September 18, 2013, 11 days after the Liberal-National Coalition won back power in the federal election, then-Prime Minister Tony Abbott implemented "Operation Sovereign Borders," a "military-led response to combat people smuggling and to protect [Australia's] borders." ${ }^{\circ}$ Operation Sovereign Borders involved a staunch commitment that all asylum seekers arriving by boat would be turned back to their country of departure. From September 2013 until July 2015, 20 boats carrying at least 633 passengers were intercepted and returned to their countries of departure, including to Sri Lanka, Vietnam, and Indonesia. ${ }^{51}$ A number of these turnbacks involved "enhanced screening" at sea, which is a cursory assessment to determine if anyone being returned is a refugee. This policy of enhanced screening prevents asylum seekers from making a detailed refugee claim and denies them any procedural fairness.

47 W. Maley, "Australia's Refugee Policy: Domestic Politics and Diplomatic Consequences" (2016) 7o(6) Australian Journal of International Affairs 670-68o.

$4^{8}$ D. Guilfoyle, Shipping Interdiction and the Law of the Sea (Cambridge: Cambridge University Press, 2009), p. 4; A. Dastyari, United States Migrant Interdiction and the Detention of Refugees in Guantánamo Bay (New York: Cambridge University Press, 2015), p. 3.

49 A. Schloenhardt and C. Craig, “Turning Back the Boats': Australia's Interdiction of Irregular Migrants at Sea" (2015) 27(4) International Journal of Refugee Law 536-572 at 538, https://doi . org/10.1093/ijrl/eev045.

$5 \circ$ Ibid., at 548 .

${ }^{51}$ J. Phillips, "Boat Arrivals and Boat 'Turnbacks' in Australia since 1976: A Quick Guide to the Statistics," Parliamentary Library, Parliament of Australia, September 11, 2015, www.aph.gov .au/About_Parliament/Parliamentary_Departments/Parliamentary_Library/pubs/rp/rp1516/ Quick_Guides/BoatTurnbacks. 
The policy of enhanced screening was first introduced in 2012 by the Labor Government to apply to Sri Lankan boat arrivals, and was mostly undertaken in Australian territory on Christmas Island. ${ }^{52}$ As part of Operation Sovereign Borders, the policy of enhanced screening was implemented while asylum seekers were detained on Navy and Custom vessels at sea. This policy involves:

asking each of the asylum seekers a set of four questions and determining their refugee status on the basis of their answers to these questions (the asylum seeker's name, country of origin, where they had come from, and why they had left) without a right to appeal a negative decision. ${ }^{53}$

The risk that a person would be returned to face harm following such a cursory assessment of their claim is high, as seen when asylum seekers from Vietnam who were turned back by Australia were subsequently granted refugee protection by the UNHCR in Indonesia. ${ }^{54}$

Australia's policy of enhanced screening and turnbacks was highlighted in the case of CPCF v. Minister for Immigration and Border Protection, 55 in which a boat of 157 Tamil asylum seekers was intercepted en route to Australia from India. After initial attempts to return the asylum seekers to India, and a subsequent High Court challenge, the asylum seekers were taken to the extraterritorial processing center on Nauru. This is the only boat of asylum seekers not to be returned since the beginning of Operation Sovereign Borders. ${ }^{56}$

Both the physical act of interdicting boats at sea and the return of individuals to transit or refugee-producing countries place refugees and others seeking Australia's protection at risk of serious harm including further persecution and even death. There are grave concerns that the cursory status determination procedures undertaken at sea to identify individuals in need of protection are inadequate to safeguard refugees who must be protected from persecution.

\section{EVALUATING THE LEGALITY OF AUSTRALIA'S POLICIES}

Australia's response to refugees is consistent with the view that a refugee is a potential threat, rather than someone fleeing harm. Under international law, states do have a sovereign right to control their borders. Inherent in the principle of sovereignty are the principles of territorial supremacy and self-preservation. This

52 M. Grewcock, "Back to the Future: Australian Border Policing under Labor, 2007-2013" (2014) 3(1) State Crime Journal 102-125 at 111.

53 Schloenhardt and Craig, "Turning Back the Boats," at 554.

54 S. Sebban, "Turned Back by Australia, Vietnamese Recognised as Refugees in Indonesia," The Sydney Morning Herald, June 11, 2017, www.smh.com.au/world/turned-back-by-australia-viet namese-recognised-as-refugees-in-indonesia-201706o8-gwn475.html.

55 CPCF v. Minister for Immigration and Border Protection, 255 CLR 514 (HCA 2015).

${ }_{56}$ Phillips, "Boat Arrivals in Australia: A Quick Guide to the Statistics." 
principle of sovereignty allows states the "freedom to act unconstrained and the right to exclude foreigners from their territory." ${ }^{57}$ Yet this absolute sovereignty has been partially relinquished through the voluntary ratification of international treaties. By agreeing to be bound by international treaties, including international human rights law, states have taken on additional obligations to uphold certain rights for both citizens and non-citizens within their jurisdiction. As Goodwin-Gill and McAdam note:

The refugee in international law occupies a legal space characterised, on the one hand, by the principle of State sovereignty and the related principles of territorial supremacy and self-preservation; and, on the other hand, by competing humanitarian principles deriving from general international law (including the purposes and principles of the United Nations) and from treaty. ${ }^{5}$

International law, and in particular the right to seek asylum and obligations of the Refugee Convention, poses a challenge to the traditional concept of sovereignty. Although the right to seek asylum is provided in Article 14 of the Universal Declaration of Human Rights (UDHR), ${ }^{59}$ it is often referred to as an empty right because it does not create a subsequent duty upon states to grant asylum. ${ }^{60}$ Indeed, the Declaration on Territorial Asylum reiterates that the granting of asylum is an "exercise of [State] sovereignty." ${ }^{\text {"1 }}$ Nevertheless, although states may not have a duty to grant asylum, they do have an obligation to provide access to their asylum procedures. Goodwin-Gill and McAdam argue that "while individuals may not be able to claim a 'right to asylum,' states have a duty under international law not to obstruct the right to seek asylum."

In addition to the UDHR, the Refugee Convention and its ${ }_{1967}$ Protocol provide further obligations on states with regard to their borders. By ratifying the Refugee Convention, states forfeit their claim to absolute control over their borders. One hundred and forty-six states, including Australia, have ratified the 1967 Protocol, which affirms the obligations of the Refugee Convention and removes its temporal and geographic limitations to post-Second World War Europe, transforming it into a set of global commitments. As Gammeltoft-Hansen argues, "refugee law places a constraint on the otherwise well-established right of any state to decide who may

57 Gammeltoft-Hansen, Access to Asylum, p. 13.

$5^{8}$ G. S. Goodwin-Gill and J. McAdam, The Refugee in International Law (3rd ed., Oxford: Oxford University Press, 2007), p. 1.

59 Universal Declaration of Human Rights, December 10, 1948, United Nations General Assembly Res. 217A(III), art. 14.

60 S. Kneebone, Refugees, Asylum Seekers and the Rule of Law: Comparative Perspectives (Cambridge: Cambridge University Press, 2009), p. 10.

61 United Nations General Assembly Res. 2312 (XXIX), Declaration on Territorial Asylum (December 14, 1967), art. 1(1).

62 Goodwin-Gill and McAdam, The Refugee in International Law, p. $35^{8}$. 
enter and remain on its territory." ${ }^{63}$ In other words, while states are entitled to build walls, these walls must have doors for refugees. ${ }^{64}$

\section{Refoulement of Refugees}

One significant danger of Australia's extraterritorial actions is the refoulement, or return, of refugees to a place where they may face persecution. This is a significant risk when Australia returns boats to refugee-producing countries directly, such as when it interdicts and returns vessels to countries of origin such as Sri Lanka and Vietnam. It also remains a risk when refugees are returned to, or are kept in, transit countries from which they may be subject to chain refoulement (the subsequent return of refugees to the original country they were fleeing).

The refoulement of a refugee is prohibited under Article 33 of the Refugee Convention. If any individuals returned by Australia are at risk of torture, Australia's actions would also violate Article 3 of the Convention against Torture and Other Cruel, Inhuman or Degrading Treatment or Punishment (CAT). Furthermore, the return of a person to inhumane, degrading treatment, punishment, or to death is a violation of Articles 6 and 7 of the International Covenant on Civil and Political Rights (ICCPR).

\section{ACCESS TO TERRITORY}

International refugee and human rights law does not explicitly grant permission for refugees to enter a state's territory. However, there is a link between compliance with a state's negative obligation to prevent refoulement and the positive obligation to provide refugees access to the territory of a state. This is because a state's nonrefoulement obligations do not end at its borders. A state, such as Australia, owes a non-refoulement obligation to anyone in its effective de jure or de facto control. Put simply, any refugee that is either directly or indirectly in Australia's control, such as individuals detained in Australia's extraterritorial processing centers or interdicted at sea, may be owed a non-refoulement obligation. Unless Australia provides protection to everyone that it has de jure or de facto control over, it must carry out fair and effective procedures to determine who is a refugee and is thus owed non-refoulement obligations, and who can be safely returned.

Hathaway argues that when there is a real risk of persecution due to a Refugee Convention ground, a duty of non-refoulement amounts to "a de facto duty to admit the refugee since admission is normally the only means of avoiding the alternative,

${ }_{3}$ Gammeltoft-Hansen, Access to Asylum, pp. 12-13.

${ }^{6}$ V. Moreno-Lax, "Must EU Borders Have Doors for Refugees? On the Compatibility of Schengen Visas and Carriers' Sanctions with EU Member States' Obligations to Provide International Protection to Refugees" (2008) 10(3) European Journal of Migration and Law 315-364, https://doi.org/10.1163/157181608X 338180 . 
impermissible consequence of exposure to risk." ${ }^{65}$ The Executive Committee of the United Nations High Commissioner for Refugees (UNHCR ExCom) agrees. In its 1997 Conclusions on Safeguarding Asylum, UNHCR Excom drew attention to the importance of the principle of refoulement and "the need to admit refugees into the territories of States, which includes no rejection at frontiers without fair and effective procedures for determining status and protection needs." ${ }^{26}$ The UNHCR ExCom in its 1998 Conclusion reaffirmed this statement and again strongly deplored the refoulement of refugees. ${ }^{67}$ In addition, in its Protection Policy Paper on Maritime Interception Operations, the UNHCR noted in 2010 that "claims for international protection made by intercepted persons are in principle to be processed in procedures within the territory of the intercepting State." ${ }^{\prime 68}$ The paper explains that interritory processing will generally be "the most practical means to provide access to reception facilities and to fair and efficient asylum procedures." ${ }^{\text {"9 }}$

\section{Arbitrary Detention}

Refoulement is not the only obligation that may be violated by Australia's current policies. As explained earlier, all refugees who arrive in or are intercepted while attempting to enter Australia can be transferred to and detained in Australia's extraterritorial detention facilities in Nauru and Papua New Guinea. Detention in these two countries is mandatory for people whose claims are being processed.

The Human Rights Committee has expressed the view that "detention should not continue beyond the period for which the State can provide appropriate justification," and that the factors necessitating detention must be "particular to the individual." 70 The ongoing detention of refugees transferred to Nauru and Papua New Guinea does not comply with this requirement. All individuals are detained regardless of their age, gender, nationality, or any other characteristic. The detention, therefore, is not particular to the individual circumstances of each person. It is thus likely that mandatory detention in Australia's extraterritorial centers violates the prohibition on arbitrary detention provided in Article 9(1) of the ICCPR.

${ }_{5}$ Hathaway, The Rights of Refugees under International Law, p. 301.

66 Conclusion No. 85: Conclusion on International Protection, Executive Committee of the High Commissioner's Programme, U.N. Doc. A/53/12/Add.1 (October 9, 1998) (emphasis added).

67 Ibid.

68 United Nations High Commissioner for Refugees, Protection Policy Paper: Maritime Interception Operations and the Processing of International Protection Claims (November 2010), www.unhcr .org/refworld/docid/4cdızdzaz.html.

69 Ibid.

70 United Nations Human Rights Committee No. 560/1993, A v. Australia, U.N. Doc. CCPR/C/ 59/D/560/1993 (April 30, 1997), 9 9.2. 


\section{Poor Conditions of Detention}

The poor conditions of detention centers also violate international law. The UNHCR has observed that asylum seekers in Nauru are kept in "cramped conditions, with very little privacy, in very hot conditions, with some asylum seekers sleeping on mattresses on the ground." ${ }^{11}$ These inadequate conditions, which compromise the health of asylum seekers and refugees, are further exacerbated by:

- Lack of adequate medical facilities, including for heart conditions, dental issues, and, in one case, to address a metal plate embedded in one person's leg.

- Hygiene issues: many complained of skin conditions and other infections, including parasites and lice.

- Lack of a gynecologist for the women.

- Lack of access to x-rays and other medical equipment.

- Limited access to medication. ${ }^{72}$

Furthermore, as stated earlier, asylum seekers and refugees transferred by Australia to Nauru and Papua New Guinea have also been subject to both sexual and physical abuse. $^{73}$

Article 10 of the ICCPR requires states to treat detainees with "humanity and with respect for the inherent dignity of the human person." The Human Rights Committee has stated that "States parties should ensure that the principle stipulated [under Article 10 of the ICCPR] is observed in all institutions and establishments within their jurisdiction where persons are being held." 74 The lack of medical care and cramped, hot conditions of detention are inconsistent with humanity and respect for the inherent dignity of the human person, and thus violate Article 10 of the ICCPR.

The conditions of detention may also violate Article 7 of the ICCPR, which prohibits cruel, inhuman, or degrading treatment. In General Comment No. 20, the Human Rights Committee states that, "[i]n the view of the Committee, States parties must not expose individuals to the danger of torture or cruel, inhuman or degrading treatment or punishment upon return to another country by way of their

${ }^{11}$ United Nations High Commissioner for Refugees, UNHCR Monitoring Visit to the Republic of Nauru 7-9 October 2013.

72 Ibid.

73 P. Farrell et al., "The Nauru Files: Cache of 2,00o Leaked Reports Reveal Scale of Abuse of Children in Australian Offshore Detention," The Guardian, August 10, 2016, www.theguardian .com/australia-news/2016/aug/10/the-nauru-files-200o-leaked-reports-reveal-scale-of-abuse-ofchildren-in-australian-offshore-detention.

74 United Nations Human Rights Committee, General Comment No. 21, Humane Treatment of People Deprived of Liberty (April 10, 1992), p. 1, www.un.org/ga/search/view_doc.asp?symbol= HRI/GEN/1/Rev.1. 
extradition, expulsion or refoulement." 75 The UN Special Rapporteur Against Torture has found that numerous aspects of Australia's policies in Papua New Guinea violate the right of detainees "to be free from torture or cruel, inhuman or degrading treatment." ${ }^{6}$ This is in violation of Articles 1 and 16 of the CAT. The finding of torture or cruel, inhuman, or degrading treatment against vulnerable individuals who had sought Australia's protection highlights the brutality of Australia's border protection policies.

\section{CONCLUSION}

Australia has sought to control its borders by both air and sea by acting outside its territory. Sadly, this has come at a significant cost for the safety and security of vulnerable groups including refugees and has placed Australia in violation of its international obligations. The Australian prime minister has stated that Australia's border protection policies are "the best in the world." ${ }^{77}$ Unfortunately, many world leaders, particularly in Europe, agree and are looking to emulate Australia's extraterritorial methods. ${ }^{78}$

Carrier sanctions, airline liaison officers, and the use of technology have limited the ability of protection seekers to come to Australia irregularly by plane while interdictions at sea, outside of Australian waters, have prevented the entry of those seeking protection by boat. Extraterritorial deterrence measures such as third country immigration detention has also acted as a discouragement to any refugees wishing to seek asylum in Australia by arriving by boat. Australia's actions have led to the refoulement of refugees, arbitrary detention, and poor conditions in detention. Such a regime cannot be "the best in the world" and must be dismantled immediately to ensure Australia's compliance with its international obligations.

75 United Nations Human Rights Committee, Compilation of General Comments and General Recommendations Adopted by Human Rights Treaty Bodies (May 27, 2008), $\uparrow$ 9, www.ohchr .org/Documents/HRBodies/TB/HRI-GEN-1-REV-9-VOL-I_en.doc.

${ }^{7}$ United Nations Human Rights Council, Report of the Special Rapporteur on Torture and Other Cruel, Inhuman or Degrading Treatment or Punishment, Juan E. Méndez (Addendum) (March 5, 2015), www.un.org/ga/search/view_doc.asp?symbol=A\%2FHRC\%2 $28 \%$ 2F68\%2FAdd.1\&Su bmit=Search\&Lang=E.

77 P. Karp, “Turnbull Claims Australian Border Policies 'Best in World' Despite Widespread Criticism," The Guardian, September 17, 2016, www.theguardian.com/australia-news/2016/sep/ 18/malcolm-turnbull-australias-border-protection-policy-the-best-in-the-world.

${ }^{8}$ D. Ghezelbash, Refuge Lost: Asylum Law in an Interdependent World, Cambridge Asylum and Migration Studies (Cambridge: Cambridge University Press, 2018). 